\title{
Asia’s Stunted Economic Development
}

"Yes, China is slowing down, but compared to the West, its GDP growth is enviable," once said Jon Copestake of the Economist Intelligence Unit. ${ }^{1}$ This is a familiar refrain in media reports, international conferences and business discussions.

But all economies which are behind world leaders (like the US and Germany) have great potential for rapid, catch up growth. And the further they are behind, the faster they can grow, just by absorbing knowledge and technology from world leaders. This is the "benefit of backwardness".

It is thus not surprising that China should still be growing so quickly. Its GDP per capita is still only one-quarter of that of the US. It would be much more surprising if China were not growing so quickly. The real disappointment is that so many other countries cannot get their act together to achieve fast, catch up growth.

The main question facing China today is whether it can stay the course in catching up to world leaders, because other Asian economies like Japan, Korea and Taiwan have not managed to do so.

Indeed, the post-war waves of high-growth Asian economies, beginning with Japan, have been arrested. Asia's major economies now face the prospect of permanently stunted development. There is now very little prospect of full catch up to the world's leading economies in terms of GDP per capita, and economic, business and technological sophistication.

(c) The Author(s) 2018

J. West, Asian Century... on a Knife-edge, https://doi.org/10.1007/978-981-10-7182-9_2 
Japan's very rapid recovery from the ashes of World War 2 took the world by surprise. Many economists were then pessimistic about the prospects for Asia, which suffered greatly from the War. The continent had few natural resources and an enormous population compared with Africa and South America. But as Japan's growth continued, many then believed that Japan would overtake the US, in much the same way that the US overtook the UK in the nineteenth century.

Japan's economic dynamism inspired the four Asian Newly Industrializing Economies-Hong Kong, Korea, Singapore and Taiwanon a similar path of rapid development. This gave rise to talk of an "Asian miracle" by the World Bank ${ }^{2}$ and others, and the group was labeled the Asian tigers.

Much ink has been spilt in analyzing the rise of these Asian economies. The main factors were their export-orientation, good education, macroeconomic stability and strong government leadership. But as Ian Buchanan has argued, ${ }^{3}$ geopolitics also played an important role in the context of the Cold War, as the US offered official assistance and open markets to its friends in Asia. And all of these successful economies were motivated to become strong in the face of their threatening neighborhoods, as they faced Mao's China, North Korea and the USSR.

But the shortcomings of the Japanese model became all-too-apparent following a financial crisis in the early 1990s. Japan (and Korea and Taiwan) has since failed to both reform its economy and deal with demographic decline. The prospect of these economies catching up to world leaders now seems remote.

Singapore and Hong Kong are rare birds in Asia, in that they have caught up to the US and Germany, and in Singapore's case well overtaken them. There are some very simple reasons. Both are Asia's only two genuine open market economies, with large immigrant populations, in contrast to Japan, Korea and Taiwan. They are also financial centers and tax havens, which allow Asia's super rich to hide their (often ill-gotten) wealth from the taxman. When these city economies are compared with other financial centers like London, New York or Switzerland's Zurich, their success seems much less surprising.

The next group of Asian economies to take off in the region's "flying geese" pattern ${ }^{4}$ of development included Malaysia, Thailand and Indonesia. Their rapid development was mainly driven by a wave of investment from Asia's advanced countries, which offshored lower-value-added activities as they climbed the development ladder. But the education and technologi- 
cal capacities of these countries are relatively weak, and their economic catch up to date remains modest. These countries would seem to be caught in a "middle-income trap", meaning that they are unlikely to graduate from middle-income to high-income status.

China stunned the world with three decades of $10 \%$ growth rates, following its opening up, which began in 1978 (more recently, Vietnam launched a similar opening to the world economy). Today, the future of the Chinese economy is problematic, as the government seems almost paralyzed by the social and political risks of undertaking reform. China may well have the world's biggest economy, but it remains a relatively poor country, with an enormous population. It also faces a grave risk of getting stuck in a middle-income trap.

India is the other Asian giant, with an enormous population. It began its reform in the early 1990s and has since achieved good economic growth. While there is a lot of positive momentum in the Indian system, it also faces immense challenges.

\section{What Is the Outlook fOR Asia's CATCH Up ECONOMIES?}

All things considered, most Asian economies have been losing some of their economic mojo, as the Asian Development Bank has argued. ${ }^{5}$ Emerging Asia's "potential economic growth rate" has fallen by almost 2 percentage points in less than a decade. The region can now only grow by about $6 \frac{1}{2} \%$, not the $8 \frac{1}{2} \%$ of yesteryear. And looking into the future, the downward slide will only continue. How could this happen?

You only have to look back to the transitory nature of some of the factors driving emerging Asia's high-growth period to glean some insights. As populations are aging in East Asia, there will be less energetic, youthful populations to drive growth. Now that many countries are already highly urbanized, there will be less new movements of people from the country to the city. Over time, the benefits of backwardness also fade as countries have copied the easy lessons from world leaders. The slowdown in China, the most important trading partner for virtually all other Asian economies, is also dragging down the economic growth potential of everyone. And the arrival of Donald Trump at the leadership of the US will likely result in a deterioration of some of the key factors that have driven Asia's development-an open US market, a relatively benign security environment and a stable global economic system. 
How to revive Asia's growth potential? There are many obvious suggestions to make like investing in human capital, technology and infrastructure; providing more opportunity to all Asians; responding effectively to Asia's poor demographics; and fully opening economies to domestic and international competition.

But digging behind the mechanical story of economic growth is a deeper story of institutions and politics. What is required for successful economic development are "inclusive economic institutions", as argued by Daron Acemoglu and James A. Robinson. Such institutions "allow and encourage participation by the great mass of people in economic activities that make best use of their talents and skills and that enable individuals to make the choices they wish". They "require secure property rights and economic opportunities not just for the elite, but for a broad cross-section of society". ${ }^{6}$ And behind inclusive economic institutions are inclusive political institutions.

The enemy of economic development is "extractive political institutions" which "concentrate power in the hands of a narrow elite and place few constraints on the exercise of this power". This elite then usually structures economic institutions in order to extract resources from the rest of society.

The analysis of Acemoglu and Robinson provides many insights into Asia's changing political economy. In the early post-war period, Asia's success stories (Japan, Hong Kong, Korea, Singapore and Taiwan) all had a great incentive to build strong economies through inclusive economic institutions. They faced threatening neighborhoods surrounded by communist regimes in China, North Korea and the USSR, and instability in Southeast Asia. They were also dependent on imports to supply their energy and other natural resources-this meant that export-oriented growth was necessary to finance imports.

In more recent decades, there has been a waning of these geopolitical threat factors. And many of the winners of economic development-big business, state-owned enterprises (SOEs) and banks- have been able to exert a strong influence over Asia's politics to keep the cards stacked in their favor.

The classic example is that of Japan where corporate and government elites, and gerrymandering of politics in rural areas, have kept the economy closed from international competition. This is a key factor behind Japan's weak productivity and failure to fully catch up to the US. Regrettably, some 70 years after Japan began its post-war recovery, democracy and 
inclusive politics still have very shallow roots. New players have great difficulty breaking through.

Similarly, Korea's enormous conglomerates ("chaebol") like Samsung and LG have a stranglehold over the nation's economy and politics, and are now holding the economy back. In China, Communist Party elites fear the creative destruction that would result from deep reform of China's grossly inefficient SOE and banking sectors. At this stage, there is little sign of reforms to ensure that market will play a "decisive" role in allocating resources, as promised in the Third Plenum in 2013.

In short, the permanence of inclusive economic institutions cannot be taken for granted. As Acemoglu and Robinson argue, "fear of creative destruction is often at the root of the opposition to inclusive economic and political institutions." One of the most visible signs of this problem is the income gap between the rich and the poor, which continues to widen in Asia. ${ }^{7}$

In conclusion, a successful Asian century will require civil society, trade unions and youth becoming much more assertive to ensure that governments are working for all citizens, not just entrenched elites. In some cases, this may require democratization and even political revolutions. In other cases, enlightened elites may respond positively to fears for their political survival. Whatever the case, without important political change, Asia will not realize its full economic and human potential, and its economic development will remain stunted.

\section{Size Matters, But Not 100\%}

Despite Asia's stunted economic development, it has enormous economic size. With $55 \%$ of the world's population, Asia's rapid economic growth has enabled it to grow its share of the world economy from 13\% in 1960 to $31 \%$ in 2015 (the West, represented by the OECD member countries, accounts for only $18 \%$ of the world's population, and has seen its share of world GDP decline commensurately). And there are a plethora of projections from organizations like the Asian Development Bank, the OECD and PWC which predict that in the coming decades, Asia will account for more than half of the world economy. ${ }^{8}$

China is already the world's biggest economy in purchasing power parity terms, even though on a per capita basis America's GDP is still four times higher than China's. India has the world's third biggest economy, but America's GDP per capita is nine times higher than India's. One 
recent set of projections by PWC shows that by 2050, China's total GDP could be $70 \%$ higher than America's, while India's could be $30 \%$ higher. At the same time America's GDP per capita could still be double that of China and triple that of India.

This shift in economic weight from the West to Asia has led many analysts to argue that there has also been a shift in economic and political power, even if Asia lags behind in terms of productivity and living standards, and economic, business and technological sophistication. It is true that their enormous economic size gives countries like China, India and Indonesia "market power" which attracts Western and other businessmen. China has large pools of investible funds that can be used for both economic and political purposes like establishing the Asian Infrastructure Investment Bank, and the Belt and Road Initiative. Large economic resources can also finance militaries which can project power and intimidate smaller neighbors, as reflected in the arms race presently underway in Asia. China, India, Japan and Korea all figure among the world's top ten for military expenditure. ${ }^{9}$

But equating economic weight with economic and political power is also too simplistic. Many Asian elites still prefer to send their children to Western universities, to migrate to Western countries in search of freedom and clean air, to buy Western companies because of their technological superiority and to invest in Western markets because of their better governance. A diminishing West still has great power, especially soft power, meaning the attractiveness of its values and culture. Without further economic, social and political development, Asia's largest economies will remain partial and fragile superpowers. It is no coincidence that China's increasing repression at home, and aggressive attitude toward its neighbors, has come at a time of fragility in its domestic economy.

An illustrative comparison of relative power in Asia is that of Indonesia and Singapore. Indonesia's total GDP is some six times bigger than Singapore's, even though on a per capita basis Singapore's GDP is some eight times bigger than Indonesia's. But the relative power of Singapore should not be underestimated. Indeed, it is not underestimated by Indonesian elites themselves who prefer to invest their savings in Singapore's vastly superior financial system, who send their children to study in Singapore's excellent schools and universities and who run to Singapore's hospitals whenever they are sick. Poorer Indonesian citizens are very happy to migrate to Singapore in search of work. And Singapore 
is strategically located at a vital access point for maritime trade routes connecting East Asia with South Asia, the Middle East, Europe and Africa.

Perhaps the greatest limit on Asia's power comes from the poor relations between very many Asian countries-for example, China-Japan, Japan-South Korea, Vietnam-China, India-Pakistan, India-China, and North Korea and very many countries. Asian countries may together account for half of the world economy in a few decades time, but they are unable to join forces in a way that they can become a dominant force. The very low trust among Asian countries means that they have difficulty cooperating together to such a point that it is questionable whether Asia even exists. Asia's power equation will also be tested over the course of the twenty-first century, with the rise of India relative to China. India's population will overtake China's in 2022, and could be some $50 \%$ higher by 2100 . And if current trends continue, India's total GDP could be bigger than China's before century's end.

After this brief diversion into what economic size means for power, in the following six sections, we will examine in greater detail the cases of Japan, Korea, China, India, Indonesia and Vietnam, Asia's most successful big economies.

\section{Japan Almost Made It!}

Japan was Asia's original miracle economy. It rose dramatically from the ashes of military defeat in 1945. In the 1950s and 1960s, Japan's annual economic growth rate was around $10 \%$, the same as China in the first three decades of its reform period. In the 1970s and 1980s, Japan's annual growth rate slipped down to the still respectable $4 \%$.

Already in 1964, less than two decades after the war, Tokyo hosted the Olympic Games and showed off to the world its high-speed train from Tokyo to Osaka (the shinkansen). Today, more than half a century later, countries like the US, Canada and Australia can still only dream of having such impressive transportation infrastructure.

Japan's high-growth, catch-up period was engineered by partnership between business, bureaucrats and politicians, the "iron triangle" 10 (the "developmental state"). Infant industries were protected from imports and inward foreign investment, and given preferential access to finance, to give the export-oriented manufacturing sector the breathing space for industrial upgrading. 
Japanese companies conquered world markets, especially for motor vehicles and electronics. Companies like Toyota and Sony were the envy of the world, as were Japanese business practices like "kaizen" (continuous improvement), lean manufacturing and just-in-time inventory management. By 1990, Japan's GDP per capita had risen to $80 \%$ of the US level.

But in the late 1980s, a real estate and stock market bubble took hold, fueled by easy money policies in response to a rising yen. The bubble was also driven by hubris and irrational exuberance. Many believed that Japan was becoming the leading global power, and that the US was set for decline. Japanese companies went on an international spending spree, as Mitsubishi bought the Rockefeller Center in Manhattan and Sony bought Columbia Pictures. And during the height of the property bubble, Tokyo's imperial palace grounds were believed by some to be worth more than all the real estate in California.

But then the bubble burst, and real estate and stock prices came crashing down again. Many banks, companies and citizens were thus saddled with large debts. The government responded sluggishly, in part due to disbelief. But the iron triangle also sought to protect enterprises and banks from the consequences of their follies. The Japanese economy would stagger through the 1990s, burdened by "zombie" or loss-making enterprises and banks that were kept afloat to ease the pain of the crisis. But in reality they only weakened the economic fundamentals by wasting finance that could have been used by new dynamic startups.

The early 1990s proved to be a major turning point in Japan's history-something which was not fully appreciated at the time, as Japan was preoccupied by the aftermath of its bubble economy. Several tectonic plates underlying Japan were shifting. Strategic, systemic adaptation was required for many reasons.

Japan's developmental state model resulted in lopsided development. While its manufacturing sector was a world leader, Japan's services and agricultural sectors were highly inefficient. Even today, productivity in Japan's services sector is only half that of the manufacturing sector. When it comes to services like finance, education, health and tourism, Singapore and Hong Kong are Asia's leaders.

Japan desperately needed fresh competition from trade and investment liberalization and deregulation to stimulate productivity in these inefficient sectors. But the very success of the iron triangle, and the constellation of interests that coalesced around it, made subsequent reform difficult, as Mark Beeson has argued. ${ }^{11}$ This includes corporate-government 
collusion through the parachuting of retired officials into high-level corporate positions, known as amakudari. And corporate governance characterized by cozy relationships fostered numerous financial scandals, most notably at Olympus and Toshiba.

Another tectonic shift was the offshoring of much of Japan's laborintensive manufacturing to other Asian countries like China, Thailand, Singapore and Indonesia, in response to the higher value of the yen, and new opportunities in these countries. ${ }^{12}$ But while the manufacturing sector was being "hollowed out", Japan remained closed to inward foreign direct investment (FDI), which even today remains at only $4 \%$ of GDP, even lower than North Korea's inward investment. This has robbed the economy of lots of opportunities to improve productivity and create decent, high-paying jobs.

Today, Japan is not a closed market for inward FDI, according to the OECD. ${ }^{13}$ And the current government has an ambitious target for doubling FDI. ${ }^{14}$ But there are very many "social practice" hurdles for foreign investors, especially constraints on labor mobility, an insular and consensual business culture which resists mergers and acquisitions, a lack of independent directors on many company boards, and cultural and linguistic barriers. ${ }^{15}$

The corporate landscape of East Asia has also changed radically. Japanese companies were once undisputed leaders in Asia, but they gradually began to struggle in the face of stiff regional competition. For example, Korea's Samsung and Taiwan's contract manufacturer Foxconn have become leaders in mobile technology, while China's Huawei and Xiaomi occupy a large slice of the low end of the market. Fortunately, Japan has developed a niche in high-tech components for many industries like mobile telephony and airplanes.

In the automobile field, Hyundai has become a challenger for Toyota, while the Chinese automobile industry is now the world's largest and is developing rapidly. Strangely, Japan does not seem to be a major player in the rapidly emerging driverless car sector. And Japanese banks are no longer globally powerful. True, Japanese companies like Softbank, Uniqlo, Muji, Nintendo and Rakuten are making their mark. But Japanese companies no longer dominate, as they once did. And this country that once boasted some great entrepreneurs is now one of the weakest performers in the OECD group when it comes to entrepreneurship.

Japan's unfolding demographic drama is perhaps the country's most important shifting tectonic plate. Japan's fertility rate has been below the 
replacement rate of 2.1 children per woman since 1975. Thus, Japan's long-awaited decline in its workforce began in 1995, while its population began its inevitable decline around 2010. This has a direct hit on the potential GDP growth rate. Indeed, the OECD reports that the economy is now only capable of growing at half a percent a year over the medium term. ${ }^{16}$ Needless to say, Japan's aging population is also giving a big hit to the government's budget deficit. And while Japan's demographic drama has been looming for decades, the government's response in terms of facilitating greater economic participation by women and admitting more migrants has been woefully inadequate. To this day, Japan remains sadly xenophobic and sexist, notwithstanding Prime Minister Abe's impressive chanting of "womenomics".

Japan's education system also desperately needs reinvention. It was very effective at promoting the literacy and numeracy of its population, things that were certainly very important when Japan was catching up to world leaders. But Japan's education system still emphasizes rote-learning, memorization and passing tests, rather than critical thinking and creativity-at a time when Japan needs to become more innovation-driven.

And while globalization has been the dominant feature of the past few decades, the Japanese are very poor at the world's global language, English. According to one survey, Japan's English-language proficiency is only "average", and behind Asian neighbors like Singapore, Malaysia, India, Korea and Vietnam, and only on par with Taiwan and Indonesia. ${ }^{17}$ This has many consequences from making life difficult for visiting tourists to isolating Japanese scholars from global networks and preventing Japan's multinational companies from becoming globally integrated enterprises. ${ }^{18}$

Japanese Nobel Prize winning scientist Susumu Tonegawa ${ }^{19}$ had some insightful comments on Japan's education: "Having spent a half century abroad since I went to the United States to study, I now regard Japan as a society rather dictated by rules. Within a fixed framework, the Japanese are able to produce things with extreme precision." In making a comparison with the US, Tonegawa argues that "A climate that respects individualistic thinking - thinking not bound by conventional wisdom-will produce revolutionary discoveries that shatter the framework. Unlike the Japanese, Americans put their own ideas first, and what others think of them is secondary. It is essential to have education that respects individual abilities and preferences."

These tectonic shifts have haunted Japan for over two and a half decades. Economic growth has been very sluggish, averaging only about 
$1 \%$ a year. Reforms to open the economy to more domestic and international competition have been proposed and discussed, but their implementation has never been serious. Japan's economy and society have been dragged down as a consequence.

Japan's GDP per capita, at $\$ 41,470$ in 2016 , has fallen back to only $72 \%$ of that of the US. Further, the country's once egalitarian society is now fracturing, as the share of people living in relative poverty has leapt from $12 \%$ in 1985 to $16 \%$ in 2012 , putting it just behind the US, with the second highest poverty of the advanced OECD countries, while income inequality is above the OECD average.$^{20}$ When it comes to child poverty, Japan now has a higher rate than the US, and $50 \%$ of single parent households live in poverty. At the same time, corporate profits are riding high at record levels.

Many visitors to Japan are shocked to hear of stories of Japanese poverty, because you do not see any beggars and street crime is virtually nonexistent. But much poverty is hidden, as it can be a subject of public shame and discrimination. And many urban homeless live in tents in public parks or on river banks.

Japan's public debt has reached world record levels at $220 \%$ of GDP, as government spending has been continuously used to keep the economy afloat. This has kept the government's friends in the construction industry happy, but also led to much wasteful spending and white elephants. Social spending on Japan's rapidly aging population has been the other factor driving debt.

As desperate as the public debt situation might seem, the government has no meaningful plan to bring it under control. Proposals to increase the consumption tax keep being postponed. The OECD has projected that it could well skyrocket to over $600 \%$ of GDP by 2060 , in the absence of decisive action. ${ }^{21}$ But before that date, markets will surely lose confidence in Japan, leading to a sharp increase in interest rates, a surge in capital flight and a crash in the yen. Japan has also suffered from deflation for much of the past two decades. Such falling prices weaken the economy, but it also exacerbates the debt problem, as the value of debt does not change, while the value of incomes and GDP are falling.

In short, Japan is caught in a "stagnation trap". But it is not too late for Japan to get its act together. After all, in recent history it has performed two miracles-one following the Meiji Restoration in the nineteenth century and the other following World War 2. But "Abenomics", the program of economic revitalization of the current government led by Prime 
Minister Shinzo Abe, is a case of too little, too late. Its monetary and fiscal stimulus arrows have achieved little. After more than four years of easy money, the goal of lifting inflation to $2 \%$ remains out of reach. Japan is now suffering from a "deflationary mindset".

The structural reform "arrow" of Abenomics, the key to improving productivity, is still sitting in the quiver. In the words of the polite and diplomatic IMF, "structural reform remains the lagging element of Abenomics." 22 Its most courageous initiative was to sign up to the Trans Pacific Partnership (TPP), but this has since been shot down by US President Donald Trump. Japan is now leading the charge to keep the TPP alive with its 11 remaining members. But it is unclear if this will happen. And the TPP without the giant US economy would be a much less important deal.

Abe and Trump have since agreed to establish a new framework for economic dialog, which could lead to a bilateral free trade agreement. But despite the chummy relations between Abe and Trump, Japan is also subject of Trump's wrath in light of its large trade surplus with the US. It is now one of four Asian countries to be put on a "Monitoring List" of major trading partners "that merit close attention to their currency practices".

One very bright spot that holds promise for Japan and indeed the international trading system is the 2017 free trade deal between Japan and the European Union which will open up Japan's agricultural sector to European farmers, and improve access to the European market for Japanese motor vehicle manufacturers. But much more bold reform will be necessary to revitalize the Japanese economy.

In conclusion, it is difficult to see anything other than a real open crisis, rather than continually creeping decline, moving this cautious and conservative country into action.

\section{Korea: The Chaebol Republic}

Heather Cho, vice-president of Korea Air, provoked a storm of controversy when she delayed the takeoff of a Korean Air flight in December 2014 , over her dissatisfaction with the service of macadamia nuts. This ridiculous incident reminded the whole world that Korea is not a people's republic. It is still a "chaebol republic".

Today, the dominant role of Korea's chaebol (large and sprawling, family-controlled conglomerates) in the nation's politics, economy and 
society is seriously questioned by many-and not just because of the "nutgate" incident. But it is still without question that the chaebol played a crucial role in Korea's rags-to-riches development miracle.

The "miracle on the Han River" was perhaps the most unlikely of all the Asian economic miracles. ${ }^{23}$ The three-year Korean War, which ended in 1953, killed $21 / 2$ million of the combined population of North and South Korea of 30 million. The peninsula's infrastructure of roads, buildings, bridges and so on was almost completely destroyed. And one-third of the population was left homeless.

At the end of the 1950s, Korea's situation still remained bleak. Then, in the space of two decades, the 1960s and 1970s, President Park Chung-hee laid the foundations for the comprehensive transformation of the Korean economy, society and politics through his "guided capitalism" (he was the father of President Park Geun-hye who was impeached in March 2017).

President Park was no believer in free markets or democracy. On the contrary, he was a ruthless dictator who came to power in 1961 following a military coup. He corralled the nation's leading businessmen into his economic development project. They were offered access to cheap finance and foreign technology, protection from imports and foreign investment, export subsidies, tax breaks, cheap labor and other favors, if they would develop industries like fertilizers, cement, chemicals, oil refining and textiles. Anticompetitive behavior like cartels, collusion and price-fixing was also tolerated. And corruption was widespread, as it still is today. Korea ranks 52nd on Transparency International's Corruption Perceptions Index (out of 176 countries), way below Japan's 20th place. ${ }^{24}$

Those who live by the sword all too often die by the sword, and President Park was assassinated in 1979. But his ruthless economic nationalism put the country on an irreversible path to prosperity and democracy, and ultimately membership of the OECD, the "rich man's club", in 1996. Within a year, Korea would be a victim of the 1997 "Asian financial crisis". The chaebol had gone an international borrowing spree, ignoring the risks of short-term, dollar-denominated debt. When international lenders then lost confidence in the Asian-miracle hype of the time, and withdrew their capital, Korea was left in financial crisis.

Korea recovered very quickly. Reforms imposed by the IMF, notably for corporate governance, opening to FDI and deregulation laid the foundation for a return to strong economic growth. But once the crisis passed, the chaebol vested interests regrouped and reasserted their influence over national policymaking. 
Electronics giant Samsung has been the star chaebol, and is now ranked the world's 10th most valuable brand by Forbes magazine, ${ }^{25}$ on a list headed by its nemesis, Apple. But Samsung is not the only one. Automobile company Hyundai is ranked 68th.

The chaebol completely dominate the Korean economy, with Samsung accounting for one-fifth of Korea's exports, and the 30 biggest chaebol for over four-fifths of exports. The chaebol's penchant for empire-building is symbolized by Samsung's 70 subsidiaries, which cover a vast array of unrelated industries like electronics, insurance, shipbuilding and petrochemicals. But they have been successful in upgrading the Korean economy from a producer of low-end manufactures to high-tech electronics and automobiles.

Overall, Korea was able to defy both history and its resource-poor geography to become the world's 14th largest economy and 7th biggest exporter. Its GDP per capita leapt from $\$ 8276$ in 1990 to $\$ 35,751$ in 2016. But it still has a long way to go in its economic catch up, as GDP per capita is only $62 \%$ of that of the US. Like Japan, Korea has a lopsided economy, where service sector productivity is less than half that of the manufacturing sector, and small enterprises are much less productive than larger ones.

The OECD estimates that Korea's potential economic growth rate has fallen from over 9\% in 1990 to only 3\% today, and since 2011 Korea's economy has been trundling along at only $23 / 4 \%$ annually. In other words, Korea faces a raft of challenges to lift its potential economic growth rate, and complete its catch up to world leaders like the US and Germany-and also to prepare the country for the possibility of having to suddenly absorb North Korea.

For one, Korea has the fastest aging population among the advanced OECD countries, as the fertility rate has plummeted from over six children per woman in 1960 to 1.2 today. This will impose an enormous drag on the economy as Korea's workforce started declining in 2016, and overall population decline could set in from 2035. In contrast to Japan, Korea has at least had the wisdom to open up significantly to immigration.

One area where Korea performs even worse than Japan is in its treatment of women. ${ }^{26}$ This is indeed a great tragedy, as providing greater opportunity to women could help Korea cope with population aging. Anyone who doubts the ability of Korean women need only look at the Ladies Professional Golf Association rankings which are dominated by Korean lady golfers. ${ }^{27}$ 
Korea also needs to transform itself from a copycat nation to a creative and innovative economy to climb further up the development ladder. Korea has indeed great potential to become an innovation nation. It leads the world in R\&D spending as a share of GDP. It has invested greatly in information technology, and is now ranked top of the world in terms of ICT development, way ahead of 10th placed Japan. ${ }^{28}$ Koreans also have a great passion for studying English, the language of the global economy. And the "Korean wave" of K-pop, television drama and cinema that has conquered East Asia, is evidence of a very creative culture.

But Korean companies are facing stiff competition from Chinese and other emerging economy companies, as well as from advanced countries. As the OECD highlights, Korea needs to strengthen international collaboration, the role of universities, venture capital, and openness to domestic and international competition to improve the foundations for innovation. And like Japan, school and university students are too focused on rote-learning, memorization and passing exams, rather than critical thinking, creativity and analytical skills.

At the heart of many of Korea's challenges is the dominant position and continued favored treatment of the chaebol, which are squeezing out the emergence of new players, which could rejuvenate the economy for new wave of productivity growth. ${ }^{29}$ The chaebol often use their market power to make it difficult for new entrants to gain a foothold. And even when new entrants do succeed, they are often acquired in takeovers by chaebol.

There is much that should be done to expose the chaebol to more healthy international and domestic competition by eliminating trade and investment barriers. Korea's market restrictions are some of the worst among the OECD group of countries, and even worse than Japan's. ${ }^{30}$

The US State Department has also highlighted Korea's weakness in the area of competition policy in noting that "the practical impact of Korea's laws and policies regulating monopolistic practices and unfair competition, however, has been limited by the long-standing economic strength of the chaebol ... Chaebol-government relations can also sometimes influence the business-government dialogue, to the detriment of foreign and small and medium-sized enterprises (SMEs)." ${ }^{31}$

Despite the reforms following the Asian financial crisis, Korea's corporate governance is still among the weakest in Asia, with complex webs of cross-shareholdings and pyramidal chaebol shareholdings, which enable owner families to exert control, but inhibit its economic efficiency and innovation performance. The Asian Corporate Governance Association 
(ACGA) ranks Korea only 8th on its list of 11 Asian countries, behind Singapore, Hong Kong, Japan, Taiwan, Thailand, Malaysia and India, and ahead of only China, the Philippines and Indonesia. ${ }^{32}$

Over the years, there has been a series of chaebol scandals related to various financial crimes. Seven of the leaders of Korea's ten largest chaebol have been convicted of crimes such as breach of trust, corruption, embezzlement and large-scale accounting fraud. While prosecutions and court cases follow, they invariably lead to official pardons, thanks to the corrupt and cozy ties between the chaebol and government. The most recent corruption scandal involved Samsung chief Lee Jae-yong, who was sentenced to five years in prison in August 2017.

Overall, it is widely acknowledged that the Korean economy needs a more level-playing field, and that the chaebol should be brought to heel. Various governments have made some efforts to do so under the banner of economic democratization, but to little effect. Given their economic dominance, it is easy for the chaebol to scaremonger about the possible adverse effects of any reforms.

In May 2017, Mr Moon Jae-in was elected president to replace President Park Geun-hye who was impeached because of corruption and abuse of power. President Moon faces an enormous set of challenges, in addition to those outlined above. First, it is necessary to restore stability and order to a deeply polarized nation which was wracked by scandal for over six months. Second, he needs to deal with the North Korean crisis on his doorstep.

The new Korean administration also faces geopolitical fallout from its high dependence on the US and Chinese export markets. In light of Korea's large trade surplus with America, Donald Trump's US Treasury has put Korea on a "Monitoring List" of major trading partners that merit close attention to their currency practices. The US has also informed the Korean government that it wants to renegotiate their free trade agreement to remove more barriers to US business. But as the Asian Development Bank has argued, given the opposition on both sides, there is a serious risk that the free trade agreement could be annulled, despite the undeniable benefits that both sides have enjoyed. ${ }^{33}$ Meanwhile, China imposed economic sanctions on Korea as an expression of its displeasure regarding Korea's agreement with the US for the installation of Terminal High Altitude Area Defence (THAAD) system. The THAAD is designed to help protect South Korea from North Korean missiles, but China fears that it will enable the US to spy on its military. 
This vast list of challenges may seem daunting, and indeed they are. But unless the President Moon and his administration tackle them head-on, the "hermit kingdom" will become another Asian country that achieves moderate success, but is unable to realize its full potential by catching up to world leaders.

\section{China's Conundrums}

The Chinese economy of today is riddled with a collection of conundrums.

The Chinese Communist government would like to open up the economy to more market forces, but at the first sign of inevitable volatility, its knee-jerk reaction is to impose anti-market controls. It would also like innovation to become the new driver of economic growth, but repression of voices of dissent, who are often the most innovative, has only been ramped up under President Xi Jinping. It is proud of having a strong and effective state, but cannot manage seemingly basic issues like food safety. And very few other countries have benefited as much from the post-war system of multilateral cooperation, and yet China is now regularly flouting and challenging this system.

China's conundrums are the inevitable consequence of its particular development model. The Chinese Communist government gradually opened up its state-owned and centrally planned economy from 1978. The main elements were opening up to foreign investment and trade, permitting private enterprise and privatizing many SOEs. China thus stunned the world with three decades of $10 \%$ growth rates.

At the same time, the government kept an important stable of SOEs, especially in the energy, telecommunications and banking sectors. These SOEs benefit from government protection and assistance, some of which is designed to help China improve its technological capacity. These SOEs also act as agents of the Chinese state through their foreign investment activities, and through helping manage the domestic economy ("state capitalism").

There has been much debate over the role of these SOEs, especially how independent that might be of government control. Their relative share in the economy has declined in tandem with the development of the private sector, and they lag the private sector in terms of productivity and efficiency. But their importance and links to the Chinese government have only grown under President Xi Jinping's leadership. Indeed, the close link between SOEs and politics is evident by the fact that the Communist Party 
appoints senior SOE executives, whose career paths usually involve time in the government administration.

Overall, China is not at all an open market economy, as evident by the OECD's research which highlights stringent state controls on the economy and barriers to trade and investment, which have only been getting worse.$^{34}$ While private entrepreneurship is vibrant in China, especially in the technology space, when firms become large and successful, they are usually coopted into the government's sphere of influence and punished if they fall out of favor with the Party. The Chinese Communist Party does not relish the development of other sources of power. Indeed, the Party keeps firm control over the private sector and foreign enterprises through "Communist Party committees" which are embedded in their management structures.

One important instrument of industry protection through much of China's development was exchange rate manipulation. The value of the Renminbi (RMB) was kept artificially low to help exports and discourage imports. This generated balance of payments surpluses and resulted in a massive accumulation of foreign exchange reserves. This reserve accumulation was very costly to Chinese citizens who were deprived of access to imports. It also meant that there was less pressure on the Chinese industry to become more competitive and productive. But these reserves, which today are still around $\$ 3$ trillion, provide the Chinese government with financial firepower for international diplomacy (like the Asian Infrastructure Investment Bank and the Belt and Road Initiative) and foreign investment.

US President Donald Trump has called China a currency manipulator, because he believes that it is still artificially undervaluing the exchange rate. In fact, Trump is several years late in his accusation. In recent times, China has been intervening to prevent its exchange rate from falling for fear of the instability that might cause. This has not stopped Trump's US Treasury placing China on a "Monitoring List" of major trading partners that merit close attention to their currency practices.

As early as 2007, Premier Wen Jiabao warned that the Chinese economy may have looked extremely strong, but was increasingly "unbalanced, unstable, uncoordinated, and unsustainable" (the "four uns"). In particular, the environmental cost of China's development has been massive. According to the World Bank, "The costs of environmental degradation and resource depletion in China are estimated to approach 10 percent of GDP, of which air pollution accounts for 6.5 percent, water pollution 2.1 percent, and soil degradation 1.1 percent." 35 The OECD estimates that 
there were 670 premature deaths per million people in China from exposure to particulate matter and ozone concentrations in $2010 .^{36}$

When the US was struck down by the financial crisis in 2008, triumphalism was the reaction of Chinese leaders. They interpreted this as a sign of the decline of the US, and the ascendancy of Asia. This period also saw the beginning of a new Chinese assertiveness in international relations and against America and Japan, in particular.

But the Chinese government also panicked. The Chinese economy had long been dependent on exports to the US and other Western markets, and there was fear of the adverse impact on the economy. So the Chinese government launched a massive stimulus package, by pushing state-owned banks to lend money to SOEs and local governments. And all the strictures of state-owned bank dominated financial system paved the way for a boom in China's risky shadow banking sector.

As a result, China's total public and private debt rose from $150 \%$ of GDP in 2008 to over $250 \%$ in $2016 .{ }^{37}$ China's rapid debt buildup is about double than that in the US before the global financial crisis or in Korea before the Asian financial crisis. The IMF has remarked that "such large increases have internationally been associated with sharp growth slowdowns and often financial crises." 38

Much of China's debt is in the SOE sector, with corporate debt representing 125\% of GDP. Many of China's SOEs are zombie companies which are de facto bankrupt. China's government debt of $55 \%$ of GDP could jump quickly if the government were obliged to bailout SOEs or to recapitalize financial institutions. Many local government infrastructure projects are not capable of generating financial returns to enable debt repayment. And nearly half of China's total debt is directly or indirectly related to the volatile real estate sector. According to Chinese real estate magnate, Wang Jianlin, China's real estate market was the "biggest bubble in history".

Another consequence of the stimulus package is industrial overcapacity which has reached astronomical proportions across a wide range of industries like steel, aluminum, cement, chemicals, refining, flat glass, shipbuilding, and paper and paperboard. For example, China's steel production "has become completely untethered from real market demand, and is now more than double the combined production of the four next leading producers: Japan, India, the US and Russia". ${ }^{39}$

The Third Plenum of November 2013 announced a new phase of widespread reforms, with market forces set to play a "decisive role" in the econ- 
omy. The goal was to wean the Chinese economy off its investment- and export-led growth model toward one based on domestic consumption and services. With little meaningful efforts toward these ambitious goals, "supply-side structural reform" (SSSR) was adopted as the new economic policy framework in December 2015. The ambitions are cutting excess industrial capacity, destocking property inventory, corporate deleveraging, lowering corporate costs and improving innovation capacities. But there are too few signs of decisive action in pursuit of these lofty ambitions. As the Economist Intelligence Unit has argued, SSSR could be more effective if the government would only let market forces drive structural reform, rather than being a "top-down, government-driven process". ${ }^{40}$

Today, the Chinese economy has reached a major turning point, as reflected in its current slowdown. According to the country's dodgy statistics, the economy is still growing in the $6-7 \%$ range, although the reality is probably much weaker. And this growth is being heavily doped by government spending, rather than any inherent dynamism. Exports, a key driver of China's high-growth period, have been sluggish for a few years now.

China may have the world's biggest GDP in purchasing power parity terms, but its GDP per capita is only one-quarter of that of the US. While poverty has been slashed from $89 \%$ of the population in 1990 to $27 \%$ in 2010 (based on a poverty line of $\$ 3.10$ a day), only $20 \%$ of the population live on more than $\$ 10$ a day. And China only has one company, Huawei, on Forbes' list of “The World's Most Valuable Brands", while its nemesis, Japan, has five. ${ }^{41}$

The only way that China can continue to climb the development ladder and global value chain (GVC) and become an advanced economy is by reigniting its productivity genie. But since 2007, China's productivity growth has been on a sharp downward trend, after having been a key driver of economic growth during much of the reform period. This is all the more worrying now that China's labor force has also been falling these past few years, the result of the sharp decline in the country's fertility rate. With less and less workers, China must lift its productivity. China's labor productivity is only $15-30 \%$ of the level in OECD countries. ${ }^{42}$

To meet its productivity challenge, China must remove more of the shackles of central planning and communism, and become an open market economy, which it is not at all today. It's high time for the Chinese government to let market forces play a decisive role in the economy.

As the European Chamber of Commerce has argued "China is not yet an open and domestic market, but rather a patchwork of regional markets, 
each with its own unique trade and investment barriers." Indeed, local protectionism is widespread. Local governments promote favored firms. SOEs have access to subsidized credit, energy and other inputs. They are often tasked with political objectives like maintaining employment. Corporate bankruptcies are avoided by banks rolling over company loans and using local subsidies.

The World Economic Forum has highlighted the structural weaknesses of China's financial sector. ${ }^{43}$ This is dominated by large state-owned banks, which lend mostly to SOEs or large corporations with connections. It is not surprising that they have accumulated many nonperforming loans. Small and medium enterprises which could provide new dynamism to the economy struggle to obtain finance.

China's lack of capacity to innovate has also become a growing concern in recent years. Evolving from a manufacturing-based economy to an innovation powerhouse requires a holistic approach to the innovation ecosystem, including nurturing talent and technological readiness. It is a lot more than spending money on $\mathrm{R} \& \mathrm{D}$, as China has been doing. It also requires an open society with freedom of speech and academic freedom, which is less and less the case in China today.

Despite the manifest need to give market forces a "decisive role" in the economy and to reignite the productivity genie, at this stage the Chinese government lacks the courage to do so. Little real reform has actually occurred, apart from stuttering reforms to financial markets. The greatest efforts have been employed on prestige projects, like having the RMB included in the IMF's Special Drawing Rights, rather than substantial projects.

What is holding China back?

Clearly the government is concerned about social stability risks due to job losses that might result from reform in light of growing labor and other social unrest. It is also struggling with local government and SOE vested interests which might lose from reform. Many SOE managers are also members of the Communist Party's Central Committee.

It also seems that the Chinese Communist Party is still in the midst of a power struggle on the reform agenda and other issues. Moreover, surrendering control of the economy to market forces is anathema to the "control-freak" nature of the Chinese Communist Party.

There is also a political agenda which is overriding economic imperatives. To preserve his political authority in the lead-up to the 19th National Congress of the Communist Party of China, held in the autumn of 2017, 
President $\mathrm{Xi}$ could not risk an economic slowdown. The government is also attached to its goal of "building a moderately prosperous society in all respects and double the 2010 GDP and per capita personal income by 2020 ", and is already eyeing the 2021 celebrations of the centenary of the founding of the Communist Party. All of this means that the Chinese government is chasing economic growth at all costs by employing monetary and fiscal stimulus, and adding further to debt, rather than implementing much needed structural reform.

In addition to managing the complexity of Chinese politics, Xi Jinping is having to cope with the unpredictability of Donald Trump's politics. During the election campaign and before his inauguration, Donald Trump had much to say about China when it comes to trade, exchange rates, South China Sea, North Korea, climate change and so on. But the Chinese know very well that American presidents say one thing during election campaigns and other things once they are in office. While Xi Jinping has been working very hard to maintain stable relations, his honeymoon with Donald Trump was quickly over, as Trump became quickly frustrated at China's token efforts to control North Korea's nuclear and missile programs and launched an investigation into China's alleged theft of US intellectual property.

Despite China's economic (and political) travails, its enormous economic size does matter. As we have argued earlier, China is able to exert its market, financial and military power in many ways. For example, the magnet of China's large market makes many foreign enterprises and governments cave into many Chinese demands. Apple has removed apps from its China store that helped Internet users evade censorship, and has agreed to open a data center in China which may give Beijing access to troves of personal and industry secrets. And now that China is the leading trading partner of most Asian countries, the Chinese government routinely employs trade sanctions to express its displeasure at the actions of other Asian governments, as countries like Japan, Korea and the Philippines have experienced. China also froze political relations with Norway and blocked many business ties and joint research and academic relationships after the Nobel Peace Prize was awarded to Chinese dissident Liu Xiaobo in 2010. It took six years of quiet diplomacy in order to renormalize China-Norway ties.

Western governments now routinely "go soft" on criticizing China's human rights, out of fear of upsetting Beijing. China regularly uses its enormous foreign exchange reserves to buy subservience from Southeast 
Asian countries concerning the South China Sea dispute. Beijing is also openly buying political influence in countries like Australia and the US. It has also been using its growing military strength to intimidate its Southeast Asian neighbors and to threaten India.

While it has been able to transform economic weight into economic, political and military power, China remains a fragile superpower which seems externally strong, but is internally weak. ${ }^{44}$ The CCP's grip on power is dependent on its capacity to deliver a strong economy, at a time when the risks of financial crisis and stagnation are only rising. And rather than accelerating economic reform, $\mathrm{Xi}$ Jinping's administration is only ramping up repression and controls on freedom. China is also very weak in terms of soft power. No country aspires to the Chinese economic or political model. And China has extremely few friends, in contrast to its emerging rival, India.

\section{INDIA: A SLOW BURNER}

India has never managed to achieve three decades of $10 \%$ annual economic growth rates like China has. But in all its long history India has never had a centralized, authoritarian regime like China has had for over 2000 years, which could provide strong political leadership. ${ }^{45}$ India is an immensely diverse country, which is essentially a creation of the British Raj and the Indian railway system that it built. "No one person could change this country with 320 languages", once said Singapore's Lee Kuan Yew. ${ }^{46}$ This diversity makes governance in India more complex than in China. But the Indian economy has performed very well these past 25 years, and the prospects for continued development may well be very good.

India is indeed a country with a great deal of potential. For example, Indians who have migrated to the US, and their descendants, earn on average \$88,000 a year, compared with \$66,000 for all Asian Americans, and \$50,000 for Americans overall. ${ }^{47}$ Indian success stories in the US include the CEOs of Microsoft (Satya Nadella), Google (Sundar Pichai) and Pepsi (Indra Nooyi). Indian companies like Infosys, Mahindra, Mittal, Reliance and Tata succeed famously on world markets. The Indian movie industry produces more films than any other country. And the Indian Premier League is the world's most lucrative and popular cricket tournament.

And yet, the Indian economy was for many years a chronic underperformer. During India's first four decades of independence, the economy 
chugged along at the "Hindu rate of growth" 48 of about 3.5\% (or 1.3\% in per capita terms) from the 1950s to the 1980s. Despite a vibrant democracy, India's economic policies drew more inspiration from the socialism of the USSR than the capitalism of East Asia or the West. This was typical of many countries at the time, which sought to achieve economic independence through inward-looking policies, once they had achieved political independence.

A financial crisis in the early 1990s triggered a wave of economic liberalization and reform. During the following 25 years, the Indian economy has averaged $6 \frac{1}{2} \%$ annual growth and is currently the world's fastest growing large economy with growth of around $7 \frac{1}{2} \%$. India's GDP per capita more than tripled over this period, with the information technology sector playing a leading role.

Thanks to India's positive economic developments, the share of the population living in extreme poverty (less than $\$ 1.90$ a day) has more than halved over the past decade to around $20 \%{ }^{49}$ But this amounts to some 270 million people who are still suffering in "Incredible India". And despite this impressive achievement, almost $40 \%$ of the Indian population is caught between $\$ 1.90$ and $\$ 3.10$ a day in a situation of near poverty. India suffers from hunger more than most every other Asian country, even North Korea and Bangladesh. ${ }^{50}$ The Indian government desperately needs to raise more taxes to provide basic services to its citizens-the OECD reports that less than $6 \%$ of Indians pay personal income taxes. ${ }^{51}$

India's GDP per capita remains less than half that of China, and about one-tenth of America's. India's ranking as the world's third biggest economy, as well as its status as an emerging power, is highly dependent on its enormous population. And like most countries which aspire to great power status, India is spending heavily on its military and space program. On the occasion of the launch of a rocket carrying satellites, Prime Minister Modi reportedly said it marked a "moment of immense joy and pride for India".

India has suffered from rising inequality like most Asian countries. ${ }^{52}$ This has tempted Jean Drèze and Amartya Sen to observe that India looks "more and more like islands of California in a sea of sub-Saharan Africa" ${ }^{53}$ And it is true that beyond the glitter of high-tech Bangalore, Bollywood and Indian cricket, India remains a rural country, with two-thirds of its population living in the countryside. But it is also undeniable that India has made immense progress. As someone who has visited the country in 1975, 1992 and 2014, I must say that India's progress is palpable. 
In the 2014 national elections, the deeply corrupt and incompetent National Congress Party, the party of Nehru and Indira Gandhi, was soundly beaten by the Bharatiya Janata Party (BJP), under the leadership of Narendra Modi. This was the world's biggest exercise in electoral democracy and was widely applauded for its transparent, impartial and correct implementation. What is more, the transition of power from one party to the other went very smoothly. Indian governance may have its problems, notably widespread corruption, but its elections do work well. India's politics may seem chaotic compared with China's. But over the longer term, China's institutions may be more brittle and fragile, relying as they do on repression, censorship and propaganda.

Prime Minister Narendra Modi has been now leading the country for over four years. He promises so much, based on his successful pro-business leadership as chief minister of Gujarat state for over a decade. However, despite Modi's impressive reforms to date, India would still be a very difficult country in which to do business, according to the World Bank which ranks it 130th out 189 countries surveyed. ${ }^{54}$ The OECD judges Indian policies to not be "competition friendly"; however, it does note a positive trend for barriers to entrepreneurship, and trade and investment. ${ }^{55}$ There has been another positive trend in the World Economic Forum's Global Competitiveness Report where, after five years of decline, India has bounced back over the past two years to 39 th place out of $138 .^{56}$ This is due to significant improvements initiated by Prime Minister Modi, whose pro-business, pro-growth and anti-corruption stance has improved the business community's sentiment toward the government.

India's human capital development is also hampered by one of the very worst education systems in Asia. By some estimates, half of the Indian population would be functionally illiterate. Even at the elite level, not one Indian university figures in the world top $200 .{ }^{57}$ India spends next to nothing on public health. Improving human capital will be critical for taking advantage of the half a billion young Indians who will enter the labor force over the next decade. Already more than 30\% of Indian youths aged 15-29 are not in employment, education or training, highlighting the immense challenges of reaping the demographic dividend of its youth bulge. Social discrimination is also rife in India, with a long list of victims like lower castes, religious minorities like Muslims and Christians, indigenous and tribal groups, and women.

A major element that has been lacking in India compared with East Asia has been the development of a strong manufacturing sector. India's manu- 
facturing sector has been stuck at around 15\% of GDP. The services sector, especially business process outsourcing and tourism, has been a key driver of the economy.

The East Asian model of urbanization and industrialization can be very effective for countries with large pools of lower-skilled labor. The model involves a structural transformation of the economy as low-productivity rural labor moves to urban areas to work in export-oriented factories. Today, industrialization could play an important role in India's development, since it faces the challenge of creating jobs for masses of semi-skilled young people entering the labor market, and transforming this demographic bulge into a dividend.

Fortunately, Prime Minister Narendra Modi's government is making efforts to develop its manufacturing sector. Major investments are being made in improving the country's logistics in areas like coastal shipping, highways and railways, which would help move products around. Inspired by the government's "Look East" policy, these efforts are being concentrated on the eastern side of the country, which is close to fast-growing Bangladesh and Southeast Asia. Special economic zones and economic corridors are also being developed.

The timing is right for India to become an industrial power, as China is now suffering from increasing wages, and investors like Japan are looking for new low-cost locations. This is where Prime Minister Modi's business-friendly policies are helpful. For example, the implementation of a national goods and services tax will help transform fragmented India into a common market. The government has also liberalized some policies for FDI, including through a "Make in India" initiative, with the result that flows of FDI surged to well over \$30 billion in each of 2015 and 2016. Leading companies like Foxconn, Softbank, Microsoft and Huawei are all now investing in India. Korean companies in particular are very successful in India. "A growing share of this FDI comes from the Indian diaspora of over 30 million, the largest in the world, who Prime Minister Modi has been courting," said Kingsley Aikins, CEO of DiasporaMatters. "Looking ahead, India's 'diaspora capital' in terms of people, knowledge and finance will likely become a driving force for the Indian economy."

Overall, there are strong grounds to be optimistic about India's future, even if it remains an extremely long way behind the world's leading economies in terms of GDP per capita, and economic, business and technological sophistication. In particular, Narendra Modi and his BJP party 
remain very popular and could stay in power for some time, which should enable India to make serious progress in its ambitious reform program.

Over the course of the twenty-first century, India could well emerge as Asia's leading power. Already, India's economy is growing faster than China's, a trend which could continue, unless China gets serious about economic reform. Further, India's population will overtake China's in 2022 and could be some $50 \%$ higher by 2100 , according to the UN. ${ }^{58}$ And moreover, India has more friends among other Asian countries than does China.

In short, India is a slow burner compared with China, but it is moving decisively ahead.

\section{INDONESIA'S OLIGARCHY}

When the corrupt, authoritarian regime of President Suharto crumbled under the weight of the 1997-1998 Asian financial crisis, Indonesia's future looked problematic. But it is now a democracy, which has achieved a solid economic performance, and which rapidly implemented a bold decentralization of government. However, the next phase of Indonesia's economic development could be rather challenging.

Indonesia's economy recovered quickly from the Asian financial crisis, thanks in part to reforms imposed by the International Monetary Fund. It then hitched its wings to the 2001-2010 commodity price boom, driven by rapid growth in China and India. ${ }^{59}$ Indonesia is a commodity-rich country, and it benefited greatly from the threefold increase in prices for coal, crude palm oil and rubber, all of which it has in abundance.

Indonesia's economic growth rate has been in the 5-6\% range since $2000 .{ }^{60}$ It now has the world's eighth largest economy in purchasing power parity terms, thanks in large part to its population of 260 million, the world's fourth largest. Indonesia has achieved an impressive reduction in poverty, with the share of the population living under $\$ 3.10$ a day falling from $85 \%$ in 1990 to $42 \%$ in 2012 . But the middle class is miniscule with only $5 \%$ living on more than $\$ 10$ a day. In 2013 , some $36 \%$ of all children under the age of five $(8.4$ million) were stunted, a condition which delays motor development, impairs cognitive function, and results in lower IQ and poor school performance. ${ }^{61}$ Inequality grew sharply during the commodity boom, as high-income households benefited much more than did low-income households. And GDP per capita remains only one-fifth of that of the US. 
The Indonesian government squandered the sharp rise in public revenues during this boom period, with much of the windfall being consumed via fuel subsidies which benefited higher-income families disproportionately. At the same time, public investment in infrastructure lagged economic growth, with the result that Indonesia's terrible infrastructure deficit is now worse than ever, thereby cutting the potential for growing productivity. ${ }^{62}$

Overreliance on commodity exports, which account for over two-thirds of total, has also harmed Indonesia's longer-term development prospects. Manufactured exports have slipped back in importance, and Indonesia has experienced deindustrialization. Commodity-driven growth was also accompanied by further environmental degradation and rapid deforestation, along with illegal logging and fishing.

The Indonesian economy now stands at a critical juncture, as commodity prices have fallen back again since 2011 , and its oil and gas production is in long-term structural decline. Indonesia has also been hit by China's economic slowdown.

The 2014 election victory of Indonesia's new president, Joko Widido ("Jokowi"), over ex-general Prabowo Subianto, and the smooth transition of power, was a testimony to the growing maturity of Indonesia's democracy. ${ }^{63}$ But Jokowi faces a daunting agenda to keep the Indonesian economy on a path of solid growth.

Like India, Indonesia is a difficult country in which to do business, being ranked only 91 st out of 190 countries surveyed by the World Bank, much worse than its neighbors Malaysia (23rd) and Thailand (46th).$^{64}$ Its policies toward inward FDI are very restrictive, ${ }^{65}$ especially in the mining sector, and corruption is endemic. Symptoms of Indonesia's poor infrastructure are Jakarta's reputation for having the worst traffic in the world, and logistics bottlenecks which are preventing better integration into Asia's GVCs.

If only Indonesia could improve its business and investment climate, it has great opportunity to unleash the productive potential of the economy, and become an industrial power, especially in light of China's declining attractiveness as an investment destination. And also like India, Indonesia has a large youthful population entering the workforce over the coming years, who requires employment opportunities.

But to convert Indonesia's youth bulge into a demographic dividend will require a massive improvement in its education. Some $70 \%$ of Indonesian manufacturers indicate that it is very difficult to fill skilled 
positions. In this context, Indonesia was ranked near the bottom of the 72 countries surveyed in the OECD PISA education survey of 15-year-old students. Regrettably, Indonesia Corruption Watch reports that one-third of Indonesia's education budget is misappropriated, and some 20\% of Indonesian teachers are absent from the classrooms every day.

President "Jokowi" made an impressive start to his presidency since he took office in October 2014. His decision to abolish most fuel subsidies was courageous, even if it was facilitated by the sharp fall in world oil prices. He is pushing hard to improve infrastructure. And he has launched a multitude of reform programs, though implementation is lagging greatly. But Jokowi faces very difficult political opposition in the parliament to advance his reform agenda.

However, Jokowi's greatest opponents are Indonesia's oligarchs, the vested interests of rich business and military elites. Indonesia is perhaps the classic case of an oligarchy-government of the "few", by the few and for the few, the very antithesis of the ideals of Abraham Lincoln. Indonesia's government has always been dominated by a small group who seek to distort government decision-making to favor or protect their financial and other interests - at the expense of the general population. I am reliably informed that nothing less than murder often occurs when an oligarch's privileged business position is threatened by an outsider.

Indonesia's oligarchy is reflected in the very high concentration of material wealth power, according to Jeffrey Winters. ${ }^{66}$ The total wealth of Indonesia's 40 wealthiest citizens, $\$ 71.3$ billion, is very much higher than those of Malaysia ( $\$ 51.3$ billion), Singapore ( $\$ 45.7$ billion) or Thailand ( $\$ 36.5$ billion), even though the GDPs per capita of these latter countries are much higher. Indeed, the combined wealth of this handful of Indonesian oligarchs equals some 10\% of GDP. A majority of Indonesia's oligarchs live semi-permanently in Singapore, where much of their wealth is also stashed away.

Most of today's Indonesian oligarchs grew up under President Suharto, through the corruption, licenses and privileges of his regime. As a practitioner of "sultanistic oligarchy", Suharto limited their influence and kept his oligarchy under control. But with the demise of the Suharto regime in 1997, Indonesia's oligarchs proceeded to buy up the political system.

Indonesia's oligarchs now finance all the major political parties, and have large influence over all decision-making. Both candidates in 
Indonesia's 2014 presidential elections had their election campaigns bankrolled by oligarchs, with the winner incurring immense post-election political debts. America's emerging oligarchy pales into insignificance with Indonesia's.

Indonesia has an immense policy agenda for it to continue a path of strong economic growth and poverty reduction, and to exploit the opportunities of the ASEAN Economic Community. Investments in infrastructure, education, health and social security all require public revenues for financing. But government spending represents a paltry 15\% of GDP, and must be increased by raising more government revenues. But oligarchs and many others are reluctant to pay their taxes.

The Indonesian government's tax amnesty program to encourage Indonesians to bring back money stashed overseas is a promising initiative to cure the country of its tax cheats. But the results so far are a mere drop in the bucket of this massive problem.

Looking ahead, another factor which will likely weigh on Indonesia is the prospective Islamization of the nation's politics. The April 2017 election for the position of Jakarta governor pitted Basuki Tjahaja Purnama (known as "Ahok"), a Chinese Christian, against Anies Baswedan, a Muslim who won the election. The turbulent campaign featured mass rallies led by a hardline Islamist movement, which has strengthened in recent years in a country which had been long dominated by a moderate form of Islam (more than $80 \%$ of Indonesia's population professes Islam).

In a clear sign that religious pluralism and tolerance is now under threat in Indonesia, in May 2017 Ahok was sentenced to two years in prison for blasphemy. His crime was to say that Muslim clerics had used a Koranic verse to mislead voters by telling them that Muslims were not allowed to vote for a Christian. This mood will likely spill over to national politics, as the Jakarta governor election traditionally sets the tone for the country. Jokowi, Indonesia's President, was previously Jakarta's Governor. And politics in Indonesia and its neighbor the Philippines are now being destabilized by a growing presence of the Islamic State group (ISIS).

Indonesia has great potential to succeed in its development challenge. But for a country burdened by an oligarchic democracy, and many other political and social hurdles, it will be very difficult to realize this potential. 


\section{Vietnam, the Next China?}

Vietnam began its transition from central planning toward a market economy in the mid-1980s with reforms known as "Doi Moi" or "Renovation". ${ }^{67}$ This was not a philosophical choice. With famines ravaging the country, and the loss of Cold War support from the former USSR, the government had to do something to get the country moving.

A long series of policy changes have included opening the economy to international trade and investment, and allowing private property rights and private enterprise. Reform is an ongoing process, with important milestones being a free trade agreement with the US in 2000, and membership of ASEAN in 2004, the World Trade Organization in 2007 and the TPP in 2015.

Vietnam also has an education system that delivers impressive results. The performance of 15-year-old Vietnamese students in mathematics, reading and science in the OECD's PISA study ranks 8th of the 70 countries covered, ahead of Australia (14th), the US (25th), and well ahead of its Southeast Asian neighbors of Thailand, Malaysia and Indonesia. ${ }^{68}$

Vietnam has thus been able to attract large flows of FDI. Vietnam's stock of FDI surged from $\$ 14$ billion in 2000 to $\$ 103$ billion in $2015,{ }^{69}$ representing some $53 \%$ of GDP. Investors have been attracted by Vietnam's strategic location near GVCs, its lower cost structure than China, and its political and economic stability. Japan, Singapore, Korea, China and Russia have been the leading investors in Vietnam.

These inflows of FDI have enabled Vietnam to join GVCs for products like garments, shoes and electronics. The FDI sector contributed $62 \%$ to exports in 2014, up from $47 \%$ in 2000 , and some $18 \%$ of GDP in 2014 , an increase from $13 \%$ over the same period. Trade has doubled to $160 \%$ of GDP over the past two decades, reflecting the active trade in parts and components that characterize GVCs. ${ }^{70}$ But despite this excellent performance, Vietnam's exports are dominated by unsophisticated products with low domestic value added, and limited technological spillover from foreign to domestic enterprises.

These important developments have enabled Vietnam's economy to expand impressively, averaging 6-7\% growth since the 1990s, with GDP per capita increasing fourfold to $\$ 6424$. While this may still be only $40 \%$ of China's GDP per capita, it is a very impressive achievement from a late starter in Asia's development. 
Vietnam's strong economic growth has resulted in a massive reduction in poverty. The share of its population living on less than $\$ 3.10$ a day has fallen from $77 \%$ in 1992 to $14 \%$ in 2012 . Vietnam's poverty reduction record was second only to that of China over this period. Vietnam's poverty is now highly concentrated among ethnic minorities, which account for $15 \%$ of the population and half of the nation's poor.

Like all middle-income countries, Vietnam now faces the challenge of taking its economy to the next level. This will require deeper and more challenging policy reforms. Vietnam is still ranked below Indonesia, Malaysia, the Philippines and Thailand when it comes to competitiveness, ${ }^{71}$ rule of law ${ }^{72}$ and corruption. ${ }^{73}$

Vietnam was to be perhaps the greatest beneficiary of the TPP. According to the World Bank, the TPP could have added as much as $8 \%$ to Vietnam's GDP, $17 \%$ to its real exports, and $12 \%$ to its capital stock. ${ }^{74}$ Perhaps more importantly, the Vietnam implementation plan included commitments on the part of Vietnam to allow workers the autonomy to form and operate trade unions of their own choosing. Currently, all unions must be affiliated with the government-connected trade union confederation. It can only be hoped that the efforts currently underway to save the TPP by remaining 11 signatories will achieve success. But the TPP, without the US, would be a much less attractive proposition.

Corruption is reportedly rampant, starting at the top with the prime minister and his cronies, and is getting worse. One creative trick is buying jobs that provide opportunities for corruption. For example, a corporate board position can reportedly be had for $\$ 100,000$; a national parks job brings in bribes when the incumbent turns a blind eye to illegal logging; and a job as a steward with Vietnam Airlines is said to cost about $\$ 25,000$, but provide excellent opportunities for smuggling, including smuggling money outside the country for the elite.

More serious efforts are also required to reform the SOE sector. While their role has declined, they still account for one-third of GDP, half of exports and over a quarter of domestic government revenue. And as they benefit from access to cheap capital, close connections to government regulators and policymakers, weak corporate governance, and limited competition, they are much less efficient than the private sector.

SOEs control key industries of the economy, including electricity, petroleum and gas, mining and quarrying, the water supply, and banking. Reform has become urgent because a number of SOEs are showing signs 
of financial distress, while state-owned banks are accumulating significant amounts of nonperforming loans. But the government likes SOEs because they can implement the government's policies. And many SOE bosses like them in light of the opportunities for corruption.

In short, Vietnam is still very much in transition from a centrally planned to a market-based economy. And a much greater sense of urgency and leadership will be necessary for Vietnam to continue its very rapid economic development.

Despite the country's impressive economic development, its political development is still frozen. Vietnam remains a communist dictatorship, with the Communist Party of Vietnam (CPV) ruling the country since $1975 .{ }^{75} \mathrm{It}$ suppresses all forms of political dissent, using a broad array of repressive measures. The criminal justice system is controlled by the CPV. Freedom of expression, association and assembly are tightly controlled.

Like most authoritarian regimes in Asia, the CPV faces increasing challenges to maintain its grip on power. With prosperity and education, there are growing calls for democracy and greater freedoms, and also protests against corruption, especially by the younger generation in this very young country. The Internet and various forms of social media provide an effective vehicle for expression and protest. The government's reaction is to fight back with repression, including restrictions on Internet freedom, and punishment of dissident bloggers.

This political system not only has great costs in terms of political and human freedoms. Such restrictions on freedom also limit the capacity for innovation and productivity to become new drivers of economic growth, as do restrictions on academic freedom.

Overall, Vietnam's trajectory has many parallels with that of China. But with a population which is only $7 \%$ of China's, Vietnam could only ever be compared with a Chinese province like Guangdong. Vietnam does have the potential to match China's GDP per capita one day. Its people are well-educated, diligent and aspirational. Indeed, as former Singapore leader Lee Kuan Yew once remarked, "Vietnam is the most dynamic of all the ASEAN countries."

But a new wave of high economic growth of Chinese proportions would require leadership like that of Deng Xiaoping to open up and reform the economy more seriously, and leadership like that of Xi Jinping to root out the systemic corruption that is dragging the country down. Most regrettably, such leadership is not on the horizon. 


\section{Concluding Comments}

Asia's rapid economic development starting with Japan, continuing with Hong Kong, Korea, Singapore and Taiwan, followed by Southeast Asia, China and India, has been stunning. Yet no large Asian economy has caught up with world leaders like the US and Germany in terms of GDP per capita, and economic, business or technological sophistication. And there is no likelihood of that happening in the foreseeable future. Asia is suffering from stunted development. Asia's economic and political power derives from its very large population, rather than its level of economic development.

It is not surprising that Asia's stunning economic development should result in an equally stunning improvement in the lives of Asia's citizens. But while Asia has achieved a dramatic reduction in poverty, the region is a long way short from having a middle-class society, as we examine in the next chapter.

\section{Notes}

1. CNBC (2015). Next largest retail market: Take a wild guess. Nyshka Chandran, 13 February 2015.

2. World Bank (1993). The East Asian Miracle: economic growth and public policy.

3. Buchanan, Ian (2012). Is regional economic integration enough? The search for 'Wave 3' growth. Asia Pathways, a blog of the Asian Development Bank Institute.

4. Akamatsu K. (1962). A historical pattern of economic growth in developing countries. Journal of Developing Economies, l(1):3-25, March-August.

5. Asian Development Bank (2016). Asian Development Outlook 2016: Asia's Potential Growth. March 2016.

6. Acemoglu, Daron, and James A. Robinson (2012). Why Nations Fail: The Origins of Power, Prosperity, and Poverty.

7. Jain-Chandra, Sonali, Tidiane Kinda, Kalpana Kochhar, Shi Piao, and Johanna Schauer. Sharing the Growth Dividend: Analysis of Inequality in Asia. IMF Working Paper WP/16/48. March 2016.

8. PWC. The Long View: how will the global economic order change by 2050? February 2017.

9. SIPRI. SIPRI Fact Sheet. Trends in World Military Expenditure, 2016. April 2017.

10. Katz, Richard (1998). Japan: the system that soured. The Rise and Fall of the Japanese Economic Miracle.

11. Beeson, Mark. The rise and fall (?) of the developmental state: The vicissitudes and implications of East Asian interventionism. 
12. Japan External Trade Organization (2015). JETRO White Paper and JETRO Global Trade and Investment Report.

13. OECD. FDI Regulatory Restrictiveness Index.

14. Abe, Shinzo (2013). Japan's New Growth Strategy: Bringing Rapid Reform to the Country.

15. US Department of State. Investment Climate Statement for Japan for 2016.

16. OECD (2017). Economic Survey of Japan 2017.

17. EF Indicator of efficiency in the English Language. Accessed 21 September 2016.

18. Palmisano, Samuel J. (2006). The Globally Integrated Enterprise. Foreign Affairs. May/June 2006.

19. Tonegawa, Susumu (2015). Only individual thinking can make big discoveries. Japan News, 8 January 2015.

20. OECD. Inequality. Accessed 22 September 2016.

21. OECD (2017). Economic Survey of Japan 2017.

22. IMF. Japan: 2017 Article IV Consultation-Press Release; Staff Report; and Statement by the Executive Director for Japan, 31 July 2017.

23. Tudor, Daniel (2012). Korea: The Impossible Country.

24. Transparency International. Corruption Perceptions Index 2016.

25. Forbes. The World's Most Valuable Brands 2017.

26. World Economic Forum. The Global Gender Gap Report 2016.

27. Ladies Professional Golf Association. Ranking: Top 100 Money List.

28. International Telecommunications Union. ICT Development Index 2016.

29. Witt, M.A. 'South Korea: Plutocratic State-Led Capitalism Reconfiguring'. In M.A. Witt \& G. Redding (Eds.), The Oxford Handbook of Asian Business Systems, pp. 216-237. Oxford, Oxford University Press.

30. OECD. Indicators of Product Market Regulation.

31. US Department of State (2016). Investment Climate Statements. Korea.

32. Asian Corporate Governance Association. "CG Watch 2016-Ecosystems Matter". Presentation by: Jamie Allen, Secretary General, ACGA.

33. Asian Development Bank. Asian Development Outlook 2016.

34. OECD. Indicators of Product Market Regulation.

35. World Bank and Development Research Center of the State Council, the People's Republic of China (2013). China 2030: Building a Modern, Harmonious, and Creative Society.

36. OECD. Economic Survey of China 2017.

37. OECD. Economic Survey of China 2017.

38. IMF. People's Republic of China 2017 Article IV Consultation-Press Release; Staff Report; and Statement by the Executive Director for the People's Republic of China.

39. European Chamber of Commerce in China (2016). Overcapacity in China: An Impediment to the Party's Reform Agenda. 
40. Economist Intelligence Unit (2017). China's supply-side structural reforms: Progress and outlook.

41. Forbes. The World's Most Valuable Brands. 2017 Ranking.

42. McKinsey Global Institute (2016). Meeting China's productivity challenge. August 2016.

43. World Economic Forum. The Global Competitiveness Report 2015-2016.

44. Shirk, Susan L. (2007). China: Fragile Superpower.

45. Fukuyama, Francis (2011). India vs. China. Carnegie Council for Ethics in International Affairs. Youtube clip.

46. Lee, Kuan Yew (2013). How will Lee Kuan Yew govern India? Singapore Now.

47. PewResearchCenter (2013). The Rise of Asian Americans.

48. Professor Rajkrishna, an Indian economist, coined the term "Hindu rate of growth" in 1978 to characterize the slow growth and to explain it against the backdrop of socialistic economic policies.

49. World Bank. Poverty \& Equity data. The $\$ 1.90$ poverty line may be more relevant to India than it is to other Asian countries.

50. International Food Policy Research Institute. Global Hunger Index 2015.

51. OECD. Economic Survey of India 2017.

52. Jain-Chandra, Sonali, Tidiane Kinda, Kalpana Kochhar, Shi Piao, and Johanna Schauer (2016). Sharing the Growth Dividend: Analysis of Inequality in Asia. IMF Working Paper. WP/16/48.

53. Drèze, Jean and Amartya Sen (2013). An Uncertain Glory: India and its Contradictions.

54. World Bank. Doing Business 2017.

55. OECD. Indicators of Product Market Regulation.

56. World Economic Forum. The Global Competitiveness Report 2016-2017.

57. Times Higher Education. The World University Rankings 2016-2017.

58. United Nations. World Population Prospects: key findings \& advance tables. 2017 Revision.

59. World Bank. Indonesia: avoiding the trap. Development Policy Review 2014.

60. Asian Development Bank. Key Indicators for Asia and the Pacific 2016.

61. OECD. Economic Survey of Indonesia 2016.

62. OECD. Economic Survey of Indonesia 2015.

63. Ufen, Andreas (2014). Jokowi's Victory: The End of the New Order in Indonesia? Asia Policy Brief, August 2014. Bertelsmann Stiftung.

64. World Bank. 2017 Doing Business Report.

65. OECD. FDI Regulatory Restrictiveness Index.

66. Winters, Jeffrey A. (2016). Who will tame the oligarchs? Inside Indonesia. Edition 104. April-June 2011. 
67. OECD. Agricultural Policies in Vietnam 2015.

68. OECD. Programme for International Student Assessment 2015 Results in Focus.

69. UNCTAD. World Investment Report 2016.

70. World Bank. Taking Stock reports on Vietnam.

71. World Economic Forum. The Global Competitiveness Report 2016-2017.

72. World Justice Project. Rule of Law Index 2016.

73. Transparency International. Corruption Perceptions Index 2016.

74. World Bank. Global Economic Prospects. January 2016.

75. Freedom House. Freedom in the World 2016.

Open Access This chapter is licensed under the terms of the Creative Commons Attribution 4.0 International License (http://creativecommons.org/licenses/ by $/ 4.0 /)$, which permits use, sharing, adaptation, distribution, and reproduction in any medium or format, as long as you give appropriate credit to the original author(s) and the source, provide a link to the Creative Commons license and indicate if changes were made.

The images or other third party material in this chapter are included in the chapter's Creative Commons license, unless indicated otherwise in a credit line to the material. If material is not included in the chapter's Creative Commons license and your intended use is not permitted by statutory regulation or exceeds the permitted use, you will need to obtain permission directly from the copyright holder.

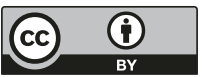

